Article

\title{
Archetypes of Green-Growth Strategies and the Role of Green Human Resource Management in Their Implementation
}

\author{
Ana Labella-Fernández
}

check for updates

Citation: Labella-Fernández, A. Archetypes of Green-Growth Strategies and the Role of Green Human Resource Management in Their Implementation. Sustainability 2021, 13, 836. https://doi.org/ $10.3390 /$ su13020836

Received: 14 December 2020 Accepted: 13 January 2021 Published: 15 January 2021

Publisher's Note: MDPI stays neutral with regard to jurisdictional clai$\mathrm{ms}$ in published maps and institutional affiliations.

Copyright: (C) 2021 by the author. Licensee MDPI, Basel, Switzerland. This article is an open access article distributed under the terms and conditions of the Creative Commons Attribution (CC BY) license (https:// creativecommons.org/licenses/by/ $4.0 /)$.
Economics and Business Department, University of Almería, 04120 Almería, Spain; alf142@ual.es

\begin{abstract}
This paper aims to develop a conceptual framework that explains how organizations address green growth. By integrating perspectives of organizational learning and ambidexterity, this paper proposes four archetypes of green-growth strategies. On the basis of exploration and exploitation dimensions, the proposed strategic green-growth archetypes are environmental-laggard, cooperative, entrepreneurial, and ambidextrous approaches. This paper suggests propositions about how to implement entrepreneurial and cooperative archetypes. It is also proposed that cooperative and entrepreneurial archetypes necessitate a set of the best and well-defined green human resource management (HRM) practices oriented towards strategic environmental goals. This paper thus proposes specific green HRM practices that better fit with each archetype. Lastly, this research concludes with a discussion of research implications.
\end{abstract}

Keywords: green growth; strategy; archetypes; exploration; exploitation; ambidexterity; green HRM

\section{Introduction}

The occurrence of natural disasters, climate change, and the depletion of natural resources are a major concern in sustaining future economic growth [1]. These concerns have generated stakeholder demands for greater environmental responsibility from organizations. Consequently, organizations are becoming increasingly aware of environmental limits, and are changing their business models by integrating social and environmental dimensions in their operations [2].

The term "green growth" has recently received a great amount of attention in the environmental management literature, with the objective to reflect the potential contribution of companies to the natural environment [3,4]. Green growth is aimed at promoting economic growth and development while preserving the natural environment. Greengrowth scholars understand environmental issues as an opportunity instead of a cost $[5,6]$, and emphasize environmental investments, quality improvements, and environmental achievements as drivers of economic growth [7].

The literature on environmental sustainability assumes that environmental strategies consist of the implementation of a number of best practices or initiatives [8,9] that companies apply to some extent. These environmental strategies are typically classified from reactive to proactive $[10,11]$ or as subsequent steps from pollution prevention to sustainable development $[12,13]$.

In this sense, the current literature assumes that environmental strategies are essentially homogeneous and that there is little variation in their nature. However, there is scarce empirical evidence about the unidimensionality of environmental strategies. When studies include several practices to measure environmental strategy, the results tend to show more than one dimension $[11,14]$.

Moreover, there is theoretical tension in the previous literature about the content of environmental strategies. On the one hand, authors describe environmental strategies as pollution-prevention approaches [13] that aim to achieve incremental resource- and operational-efficiency gains, and environmental risk minimization through the use of 
environmental management systems, life-cycle analysis, written procedures, and formal evaluations [15-17]. This approach relies on procedures and practices that require highly formalized and specific component knowledge.

On the other hand, environmental strategies also emphasize radical product and process innovation $[8,11,17]$ or business-model innovation $[18,19]$ that changes market structures. These initiatives require creative problem solving and knowledge integration, are typically less formalized, and rely on architectural knowledge that is typically not written anywhere and is dispersed in the organization. This paper argues that these two approaches are at odds with each other, have different logics, and rely on different types of knowledge.

In addition, we know little about how to implement green-growth strategies [20]. Scholars recognized that green-growth strategies necessitate the aggregation and interaction of skills and resources, which are physical assets, technology, and people $[17,21,22]$. Additionally, human resource management (HRM) is considered a key success factor in shaping organizational culture, strategies, policies, and practice development [23,24]. In the literature, HRM practices that have positive environmental outcomes are regarded as green HRM ([25]. Green HRM is particularly important in achieving green growth [26]. Scholars argued that green HRM provides organizations with an environmentally aware, committed, and skilled workforce that helps companies to minimize their environmental impact $[20,27]$. Recent research found empirical support for a positive relationship between green HRM practices and environmental performance [28-30], while others found a positive relationship between green HRM practices and sustainability performance with regard to social, environmental, and economic aspects [31,32].

Most research on green HRM focused on listing best practices [33]. However, there is a widespread assumption in strategic HRM that organizations must strive to align HRM practices with their strategic goals [34], so that organizations should implement different bundles of HRM practices depending on the strategic goals that these organizations are pursuing. Specifically, organizations should implement different approaches to green HRM and bundles of practices depending on their environmental strategy and green-growth goals. However, there is a lack of theoretical development at this point. The current literature has not sufficiently described possible alternative HRM approaches to greengrowth strategies, and has neglected to provide guidance about which green HRM practices would configure such approaches.

Therefore, the first goal of this paper is suggesting four alternative archetypes of green-growth strategies: environmental-laggard, cooperative, entrepreneurial, and ambidextrous approaches. On the basis of the ambidexterity literature, this study describes the entrepreneurial archetype (high exploration-low exploitation) on the basis of the search for radical environmental innovations and business models. This archetype requires exploratory learning, architectural knowledge, and creative excellence. The cooperative archetype (low exploration-high exploitation) is also described on the basis of the search for ecoefficiency, incremental environmental improvements, and waste reduction. The cooperative archetype relies on exploitative learning, component knowledge, and operational excellence.

The second goal of this paper consists of developing a theory about how to implement entrepreneurial and cooperative green-growth strategic archetypes, and the role of green HRM in that. A growing number of authors emphasize that the success of green strategies depends to some extent on employee behavior, commitment, involvement, and dedication $[35,36]$. Consequently, this paper proposes different configurations of green HRM practices for each of the two different archetypes: entrepreneurial and cooperative.

This study contributes to the strategic and environmental literature in two ways. Firstly, this study extends the literature by proposing a conceptual formulation of different green-growth strategies. Secondly, by highlighting the human side in the implementation of green-growth strategies, this study proposes different configurations of green HRM practices to favor the adoption of each archetype. 
This paper is organized as follows. Section 2 develops conceptually different approaches to environmental strategies. Section 3 proposes how to implement and manage the entrepreneurial and cooperative archetypes. Lastly, Section 4 sets out the discussion and conclusion of this paper.

\section{Theory and Conceptual Framework}

\subsection{Organizational Learning}

Organizational learning is a multilevel phenomenon that provides the necessary understanding about how a firm can adapt to market requirements and changes [37,38]. While organizations adjust to changing environments, they develop the capacity to learn over time by changing their knowledge or behavior [39,40].

March [41] suggested two different modes of organizational learning: exploration and exploitation. Exploratory learning "involves the search for new organizational routines and the discovery of new approaches to technologies, businesses, processes or products" [42] (p. 118). Exploration consists of the pursuit of brand new knowledge [43]. Exploratory learning is predominantly based on tacit, unwritten knowledge that is not available in books, databases, procedures, or files [41]. In addition, it mostly refers to systemic knowledge because it pursues changes (e.g., new technologies and business models) that affect the entire organization as a system [41,42].

Exploitative learning involves going in depth and refining or cultivating the current knowledge [43]. It results in incremental innovations such as better, more efficient processes and products, and in improvements in current technologies or organizational systems [44,45]. It is based on explicit knowledge, as it is written and codified and is more specific to resources, skills, and technologies [41,42]. Exploitative learning is related to identifiable parts of an organizational system instead of referring to the organization as a whole $[41,42,46]$. In terms of value creation, exploitative learning carries moderate benefits, and expected and more predictable costs [47].

Conversely, exploratory learning carries higher, less predictable costs of experimentation, but also greater potential benefits [42]. Hence, exploratory learning could be a double-edged sword. It dramatically improves firm performance because it provides flexibility to adapt to unpredictable changes [41]. However, it might also be completely unsuccessful, as it entails risky activities with few guarantees of success [47]. Conversely, returns from exploitation activities are systematically more certain, as they involve continuous improvement. However, they confer less flexibility and the ability to adapt to external changes (i.e., regulatory, economic, competitive, institutional) [48].

Both exploitative and explorative learning are valuable sources of knowledge production [48]. Knowledge acquired from exploitative learning is more routine and incremental, while knowledge from explorative learning is more diverse and unsettled [45,48]. In this context, it was argued that shared knowledge facilitates organizational learning [47]. The literature identified two forms of shared knowledge: architectural and component [49]. The next section presents both forms of shared knowledge that are linked to exploitative and exploratory learning.

\subsection{Shared Knowledge and Organizational Learning \\ 2.2.1. Exploratory Learning and Architectural Knowledge}

Architectural knowledge is holistic and systemic, as it refers to the organization as a whole or system. Such knowledge is based on complex, intangible, and tacit routines that apply everyday component knowledge owned by the organization. Moreover, these tacit routines help to generate new architectural and component knowledge [50-52]. Likewise, it is dispersed within the organization and evolves over time [51,53,54]. Architectural knowledge is, to a great extent, specific for each organization (diverse). For that reason, it may present causal ambiguity and process dependencies (unsettled) [49]. 
Architectural knowledge helps employees to pursue exploratory learning [47] because it allows for employees to understand and interpret broader and complex, unexpressed, and not articulated knowledge $[55,56]$.

\subsubsection{Exploitative Learning and Component Knowledge}

Component knowledge encompasses specific knowledge about resources, abilities, and technologies [49,51]. These resources, abilities, and technologies are typically related to the identifiable parts of an organizational system rather than being related to the organization as a whole. It is subject to discovery rather than on creation by organizations [54]. Such knowledge is relatively explicit and linked to the specific technology of an industry [52]. Therefore, it can more easily be replicated, transmitted, and copied.

Component knowledge helps employees to pursue exploitative learning [47] because it allows for employees to better understand and interpret novel component knowledge than if they had not previously acquired it $[47,57]$.

\subsection{Ambidexterity Perspective to Green-Growth Strategies}

Although it was argued that exploitation and exploration are mutually incompatible, as they represent independent self-reinforcing patterns of learning [41], the literature on organizational ambidexterity underscores that this does not mean that it is impossible to overcome these patterns [58]. The argument, in a nutshell, is that it is very difficult (but not impossible) to successfully adopt both patterns of learning at the same time because implementing these patterns of learning requires different organizational configurations. This is where the concept of ambidexterity takes part: "Ambidexterity is an organization's capacity to address two organizationally incompatible objectives equally well" [58] (p. 291).

As it seems unlikely that firms can achieve the highest level of both different and competing objectives at the same time, some scholars deduced that the same logic as the efficiency frontier of Porter [59] (e.g., [58]) could be applied. Figure 1 shows how firms could adopt different approaches to manage ambidexterity, namely, the decision of allocating resources to exploration, exploitation, or both simultaneously.

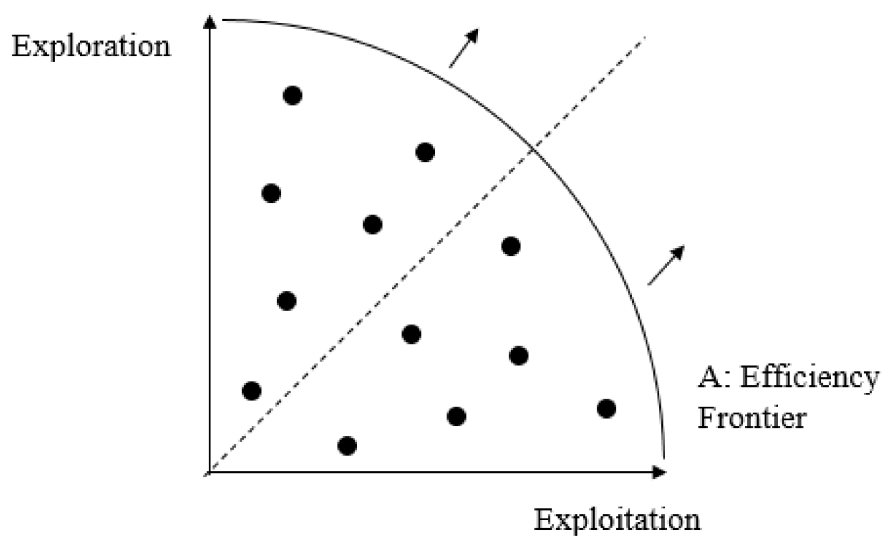

Figure 1. Approaches to managing ambidexterity [58] (p. 295).

This paper argues that it is an efficiency frontier and an environmental-value frontier. Firms can be at the environmental-value frontier in exploration, exploitation, or both at the same time. The challenge is not necessarily to find equilibrium between the exploration and exploitation dimensions (dashed line) without considering the efficiency frontier. The question is how to approach the efficiency frontier on exploration or exploitation, and how to push the efficiency frontier to the right and up [58]. Under this framework, Figure 2 shows four different strategic green-growth archetypes. 


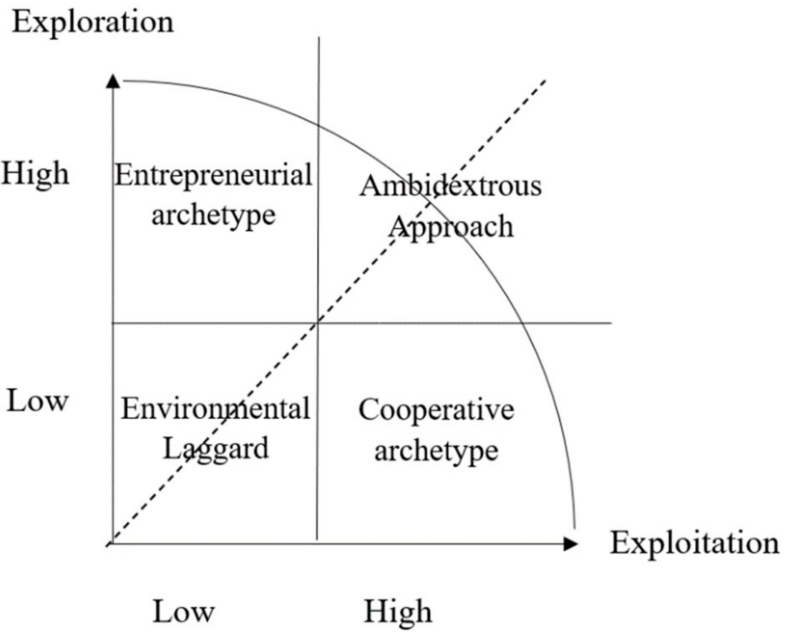

Figure 2. Approaches to green growth.

The entrepreneurial environmental management archetype (high exploration-low exploitation) aims to develop new and innovative products, processes, and markets to anticipate competition's initiatives, and technological, regulatory, and societal changes. The entrepreneurial archetype relies on exploratory learning. Hence, nonroutine tasks, associated with creativity, and product and process innovation [60], may better contribute to firm competitiveness and survival under an entrepreneurial archetype [19]. The rationale consists of applying new technologies and approaches to existing and upcoming environmental challenges or developing innovative business models to profit out of environmental demands. Tesla Motors and Patagonia INC are good examples of entrepreneurial environmental management, primarily consisting of the exploration of new technologies and business models to change the status quo and solve environmental challenges $[19,61]$. This archetype relies heavily on architectural knowledge. This knowledge provides employees with the ability to understand large amounts of knowledge that is typically complicated, unexpressed, and difficult to conceptualize [47].

The cooperative environmental management archetype (low exploration-high exploitation) develops incremental environmental improvements in already existing products, routines, and processes such as the substitution of hazardous and polluting materials, reducing resource consumption and waste during production or product usage, or other ways of reducing environmental degradation [62]. The cooperative archetype is predominantly based on exploitative learning. Therefore, it frequently relies on goal setting, records, measurements, and formal evaluations, and can be found in written procedures and environmental management systems. This archetype depends to a great extent on component knowledge. This knowledge provides employees with the necessary understanding about specific resources, abilities, and technologies of a specific industry $[47,52]$. As a case in point, DHL, world market leader in the logistics sector, has established "GoGreen solutions", a set of environmental improvements in existing services aimed to reduce the environmental impact. This plan is the result of accumulated experience and is based on formal assessment as well as organizational environmental best practices which are written in procedures. Figure 3 displays the elements of both entrepreneurial and cooperative green-growth strategies. 


\begin{tabular}{|c|c|c|}
\hline & $\begin{array}{l}\text { Economic and Environ- } \\
\text { mental value creation }\end{array}$ & \\
\hline Exploration & & Exploitation \\
\hline $\begin{array}{l}\text { Entrepreneurial } \\
\text { environmental man- } \\
\text { agement archetype }\end{array}$ & & $\begin{array}{c}\text { Cooperative } \\
\text { environmental } \\
\text { management archetype }\end{array}$ \\
\hline Exploratory & Learning & Exploitative \\
\hline Architectural & Knowledge & Component \\
\hline $\begin{array}{c}\text { Creativity, disruptive } \\
\text { innovation }\end{array}$ & $\begin{array}{c}\text { Key resource and capabili- } \\
\text { ties }\end{array}$ & $\begin{array}{l}\text { Quality management } \\
\text { and continuous im- } \\
\text { provement }\end{array}$ \\
\hline $\begin{array}{l}\text { Radical improvements: } \\
\text { new products, pro- } \\
\text { cesses, business mod- } \\
\text { els, materials, and } \\
\text { technologies }\end{array}$ & Goals & $\begin{array}{l}\text { Incremental improve- } \\
\text { ments: better products, } \\
\text { processes }\end{array}$ \\
\hline
\end{tabular}

Figure 3. Elements of entrepreneurial and cooperative green-growth strategies.

At one extreme, organizations can be found that pursue an ambidextrous environmental approach. A high level of environmental exploration and exploitation characterizes organizations seeking this approach. Organizations are engaged in the environmental exploration of new potential actions and the environmental exploitation of current possibilities. Under this archetype, organizations strive to develop mechanisms and formulas that ensure equilibrium between long- and short-term orientation. This orientation is the ultimate goal of sustainable development, focusing on "development that meets the needs of the present without compromising the ability of future generations to meet their own needs" [63] (p. 29). Although this approach is hard to achieve as two competing objectives are pursued, it characterizes companies that really pursue environmental sustainability. However, in practice, there are organizations that are more ambidextrous than others [58]. Due to it being particularly hard to maintain a balance between environmental exploration and exploitation, organizations intentionally change their position on the efficiency frontier in order to prevent remaining in one dimension in the pursuit to be ambidextrous [64]. Over time and learning from experience, organizations could learn how to find a balance between the allocation of resources to environmental exploration and exploitation [41], thus achieving the ambidextrous approach.

At the other extreme, the environmental-laggard approach is characterized by a reactive posture $[8,10,11]$. Organizations under this archetype have no intention of investing in environmental exploration or exploitation activities that reduce the environmental impact of their activities. These organizations are characterized by a lack of a competitive environmental strategy reacting to environmental market changes to maintain their position [65]. An absence of environmental concerns leads to organizations not improving existing envi- 
ronmental competences or technologies (low level of exploitation), and not experimenting with new environmental alternatives such as completely new environmental products (low level of exploration). This approach reflects a refusal to environmental management and a posture of nonresponsiveness with regard to environmental issues [65].

\section{Implementing and Managing HRM Architecture of Green-Growth Strategies \\ 3.1. Implementation of Green-Growth Strategies}

Although both archetypes require top-management commitment to environmental issues, in the entrepreneurial archetype, there could be an explicitly conscious decision of the founders to explore novel technologies and markets to create environmental and economic value. The agency role of entrepreneurs requires the managerial intention of investing precious resources in exploring new business models or technological avenues to challenge current environmental problems [66,67]. Therefore, the genesis of the entrepreneurial archetype requires specific managerial intention and investment to pursue architectural knowledge about a specific system or technology. For example, the vision of the founders of Tesla Motors was "to accelerate the advent of sustainable transport", and subsequent long-term decisions and strategies derive from that vision. This initial decision can be hardly affected by lower-level employees' initiatives and ideas. In this sense, the entrepreneurial archetype is related to a company's raison d'être. Therefore, the entrepreneurial environmental management archetype is predominantly implemented top-down.

Conversely, the cooperative green-growth strategy depends on middle managers and lower-level employees to a greater extent. Incremental environmental innovations come more frequently from employees at lower hierarchical levels [68]. This is, in part, due to the fact that employees are closer to the operations. For that reason, low and middle managers are frequently more knowledgeable of routine-based specific component knowledge than top management is. Lower-level employees are more capable of understanding the shortcomings of production processes and technologies. In this sense, it is more likely that lower-level employees come up with suggestions or ideas and take initiatives to refine and improve existing products and processes. Therefore, their role is more relevant under the cooperative archetype, so that this archetype is predominantly implemented bottom-up.

Proposition 1a (P1a). The entrepreneurial green-growth strategy is more frequently implemented top-down.

Proposition $\mathbf{1 b}(\mathbf{P} \mathbf{1 b})$. The cooperative green-growth strategy is more frequently implemented bottom-up.

In both green-growth strategies, the employees' collaborative behavior and initiatives are of paramount importance. Thus, to be effective, any environmental strategies need the active participation of employees as a source of opportunities and innovations, as indicated by [68]. Employee involvement was conceptualized as "a participative process to use the entire capacity of workers, designed to encourage employee commitment to organizational success" [69] (p. 3). Employees' environmental involvement leads to support for environmental improvement to processes and products. Furthermore, to achieve employees' environmental involvement requires the design of mechanisms [16] by a top management that favors environmental behavioral aspects and voluntary initiatives. However, each archetype is based on different learning processes, knowledge, and goals. Therefore, mechanisms designed by the organization to involve employees depend on the fit with the archetype.

In the next section, some practices that support employee involvement with the entrepreneurial and cooperative archetypes are proposed. 


\subsection{Training and Green-Growth Strategies}

Training allows for a company to align individual competences with those required by established strategies [70], and it was studied as an antecedent of environmental strategies [71]. Environmental training helps employees to be aware of the environmental impact of their organization's activities [9] and to acquire abilities to protect the environment [68]. Organizations should develop specific environmental training programs according to the demands of their organizations [72]. However, the previous literature is not clear about what type of training is more effective to develop different environmental strategies [68].

The entrepreneurial green-growth strategy, based on exploratory learning and architectural knowledge, requires a general understanding of the technological system about different technologies and raw materials that could possibly be used in the industry [9]. Effective environmental training should be focused on skills related to articulating existing knowledge and generating new knowledge. Training on new industrywide technologies and materials might better contribute to generating new knowledge instead of specific environmental skills [72]. In essence, under an entrepreneurial environmental management, training should be holistic and systemic and comprise knowledge-creation skills because it is more likely to produce new disruptive ways of approaching environmental problems.

For the cooperative green-growth strategy, specific training on work-related tasks is more effective, resulting in incremental product or process improvements and operational efficiency. Firstly, the cooperative archetype relies more on component knowledge about specific resources, abilities, and technologies than about the system as a whole $[51,53]$. Therefore, it is relatively easy to identify which part is relevant to a given functional area or operational unit, and articulate specific training activities on that knowledge. Secondly, component knowledge is relatively explicit $[53,54]$, which makes specific task-related training more effective in developing skills to optimize existing processes and improve green products.

Proposition 2a (P2a). Training on (i) industrywide technology and materials, and (ii) knowledgecreation skills favors the entrepreneurial green-growth strategy.

Proposition $\mathbf{2 b}$ (P2b). Training on (i) task-specific knowledge specialization, and (ii) specific technologies and materials favors the cooperative green-growth strategy.

\subsection{Information Sharing and Green-Growth Strategies}

The importance of environmental information sharing programs to develop environmental initiatives and strategies was suggested by researchers [22,73]. However, environmental information dissemination should be developed differently in accordance with the archetype that is pursued.

The entrepreneurial green-growth strategy demands informal conversations that exchange tacit knowledge among firm employees [15]. Casual, unwritten communication among members of organizations outside of official procedures is more effective for idea generation [73]. Architectural knowledge is complex, dispersed in the organization, and evolves in an unorganized way [51,54]. Therefore, it is very difficult to apprehend in a written form and, when it is done, it is difficult for the reader to apply it. For that reason, it is useful to eliminate barriers to environmental communication [68]. Casual encounters where tacit environmental information is shared may provide additional context to tell useful from un-useful information and expert advice to make sense of how to use the information.

Formal information sharing programs such as environmental management manuals and procedures, newsletters, and environmental reports are particularly effective under the cooperative green-growth strategy. This archetype relies on lower-level manager and employee suggestions and initiatives. When employees clearly perceive the priorities and goals of the organization via a formal information mechanism, they tend to align their behavior with that intended by the organization $[68,74]$. In addition, through formal 
information sharing programs, employees are more aware of the environmental impact of their daily routines. Consequently, employees are more conscious of the positive effect and the benefits of possible environmental changes, which leads them to greater involvement in such environmental changes.

Proposition 3a (P3a). The frequency of informal encounters favors the entrepreneurial greengrowth strategy.

Proposition $\mathbf{3 b}(\mathbf{P} 3 \mathbf{b})$. Formal environmental information sharing programs favor the cooperative green-growth strategy.

\subsection{Reward System and Green-Growth Strategies}

A well-devised reward system can be helpful in motivating employees and increasing their commitment to environmental tasks, processes, and objectives [75,76]. Calia et al. [77] argued that rewards should be in line with the results of environmental projects within organizations to improve the effectiveness of reward programs and achieve employees' environmental behavior. The literature on green HRM practices identified two types of reward systems: monetary and nonmonetary [25,78].

Nonmonetary rewards are regarded as one of the most important factors to motivate employees [79]. Ramus [68] revealed that recognition-and-praise environmental initiatives have a positive impact on supporting eco-innovation within organizations. Recognition in the organization's newsletters, publication of employees' environmental initiatives, and merit certificates to individuals and teams are commonly given to employees to motivate them [80] to achieve radical innovation.

Monetary rewards (e.g., incentives and bonuses) favor job satisfaction and work motivation [79]. Moreover, this allows for organizations to align environmental goals with employees' self-interest objectives [78]. To phrase it in another way, payments or bonuses linked to the achievement of incremental environmental goals, such as the efficient use of resources, technological efficiency improvements, and the increased use of recycled materials, might help to achieve organizational environmental goals $[75,78]$.

Although it was argued that a combination of monetary and nonmonetary rewards is more effective to motivate employees [25], this paper proposes that organizations under the entrepreneurial green-growth strategy should emphasize recognition programs more because they foster the generation of new ideas and employee creativity and innovations [68]. Nonmonetary rewards to creativity and idea generation create a positive mood about environmental innovations that favors this strategic approach.

On the other hand, under the cooperative green-growth strategy, organizations should pay more attention to monetary rewards. Monetary rewards typically require formal goal setting that includes environmental goals. These goals are commonly based on the incremental improvement of past years' environmental results, which fits the logic of the cooperative strategy.

Proposition 4a (P4a). Recognition programs for environmental creativity and innovation favor the entrepreneurial green-growth strategy.

Proposition $4 \mathbf{b}(\mathbf{P} 4 \mathbf{b})$. The implementation of bonuses linked to the achievement of incremental environmental goals favors the cooperative green-growth strategy.

Figure 4 summarizes the best practices for implementation strategies and the HRM configuration to implement and manage entrepreneurial and cooperative archetypes. 


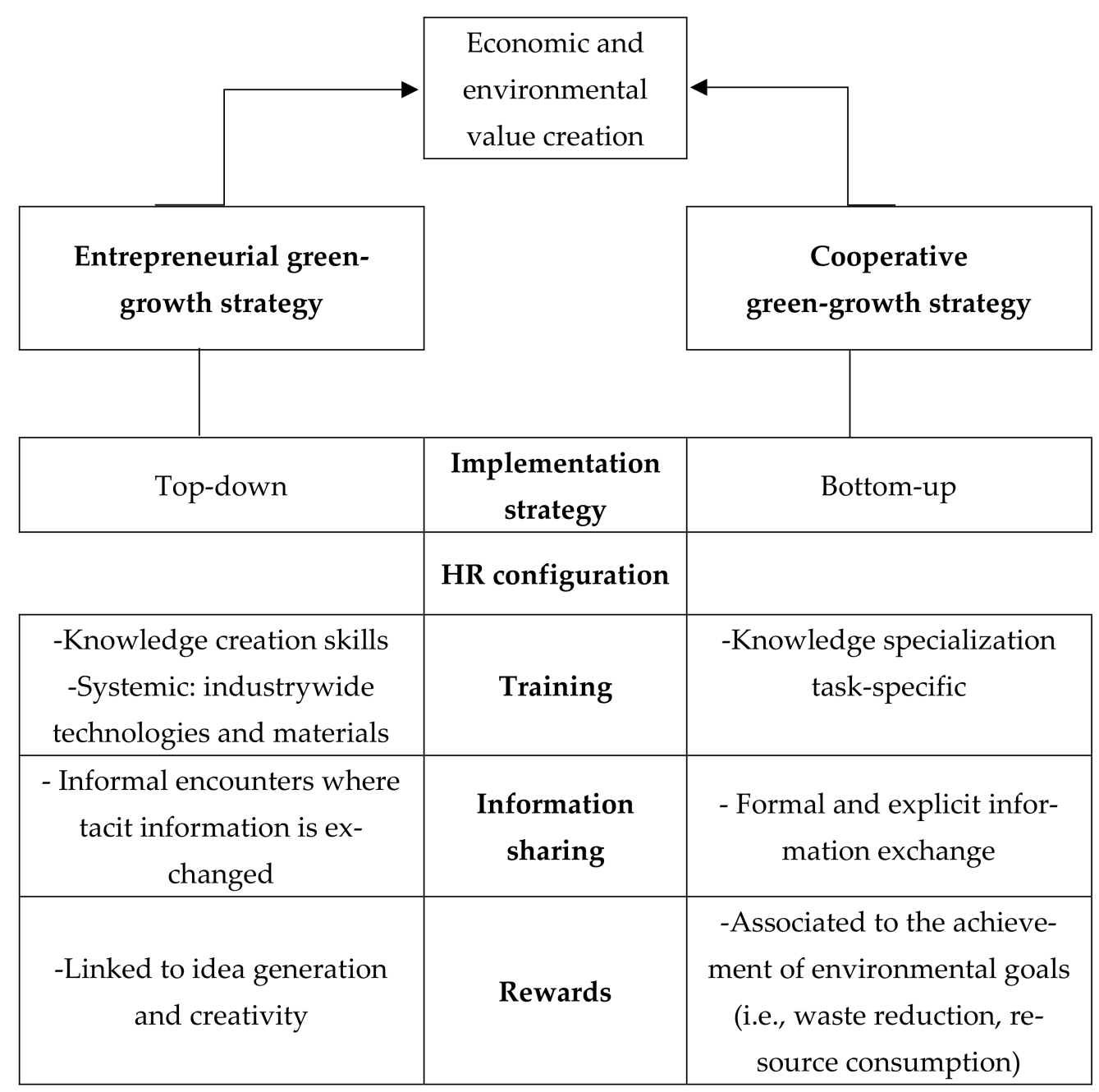

Figure 4. Implementation strategies and human resource management (HRM) configurations to manage entrepreneurial and cooperative archetypes.

\section{Discussion}

The literature on environmental sustainability suggested different corporate strategies that organizations adopt to address environmental problems and achieve green growth. These environmental strategies are commonly classified from the most reactive (end-of-pipe solutions) to the most proactive (sustainable development solutions) positions $[10,11,13]$. This paper aimed to contribute to this research stream. It offers a new conceptual model that incorporates the concept of ambidexterity into environmental strategies. In this regard, it integrated the perspective of organizational learning and ambidexterity to propose a fresh theoretical framework. On the basis of two types of organizational learning, exploitation and exploration, four possible approaches were identified for managing environmental sustainability. Firstly, the environmental-laggard approach is characteristic of organizations that lack environmental concerns and do not invest in environmental exploration or exploitation. Secondly, organizations under the entrepreneurial archetype focus on the environmental exploration of new environmental possibilities within a specific industry. These types of organizations seek to place themselves in an environmental-market leadership position by applying new technologies and developing new business models. Thirdly, the cooperative archetype is characteristic of organizations that seek to maintain their position in the market by exploiting current environmental possibilities and developing environmental incremental innovations to achieve operational excellence. Lastly, the ambidextrous approach describes organizations that seek both environmental exploitation and environmental exploration. These types of organizations seek to be leaders regard- 
ing environmental issues by exploring promising opportunities and exploiting current environmental opportunities. Hence, our work frames the environmental challenges that organizations face through the lens of the ambidexterity theory. The four approaches represent different positions that organizations can adopt regarding environmental problems.

Moreover, this study proposes how to implement both entrepreneurial and cooperative archetypes. Environmental green-growth strategies do not always have to be implemented top-down. The participation of employees in decision making plays a key role to achieve operational efficiency since they know better processes and might come up with environmental solutions to continuous improvement. Operational efficiency is traditionally related to the formalization of routine tasks, written procedures and formal evaluations [81]. This paper also provides insight into the proper alignment between the green-growth strategy archetypes and the green HRM practices to manage and implement them [34]. To date, several works have provided insight into green HRM practices that could be useful to attain employees' environmental involvement, creativity, and commitment [25]. Although previous studies have also addressed how green HRM practices can reduce the environmental impact of firms, little effort has been made to identify green HRM practices that support different environmental management strategies. In this sense, considering that organizations should implement specific green HRM practices according to their environmental management strategy, this paper proposes different green HRM practices for managing and developing each archetype. Therefore, by better understanding the depth of green HRM practices, organizations might improve their environmental and financial performance. Green HRM practices are of paramount importance in making organizations and their operations more sustainable in reducing environmental degradation.

An ambidextrous environmental approach (a balance between the cooperative and entrepreneurial archetypes) has the highest positive impact on environmental sustainability. However, this approach is really hard to achieve [58], as two different competing objectives and organizational configurations are pursued. It is really difficult to pursue environmental exploitation and exploration due to several reasons. Firstly, the necessary knowledge is completely different. While the entrepreneurial archetype demands architectural knowledge, the cooperative archetype requires component knowledge. Secondly, the implementation is also different. The entrepreneurial archetype tends to be implemented top-down, whereas cooperative archetype implementation tends to be bottom-up. Thirdly, green HRM practices that support each green-growth strategy and help to manage them are configured completely differently to foster each competing objective. These reasons might lead most organizations to opt for one option: the entrepreneurial or cooperative strategic green-growth archetype. The pursuit of the two competing objectives entails the risk of becoming stuck in the middle and not achieving either objective.

This study also carries important implications for practitioners. This paper, by advancing the understanding on how organizations could adopt different environmental postures, will help managers to develop the strategy that better fits with their environmental objectives. For the effective implementation of green-growth strategies, organizations can adapt green HRM practices to their environmental strategic goals. Proper training, information sharing, and reward systems can play crucial roles in developing green-growth strategies.

\section{Conclusions}

With the increasing recognition of environmental responsibility, organizations are implementing different green-growth strategies. However, limited research is available to guide the effective implementation of different environmental strategies. This paper was an effort to join green-growth strategies with green HRM practices.

Despite the contributions provided by this work, much remains to be done. Future research should be required to operationalize the model by using quantitative methods. Moreover, researchers are encouraged to consider other green HRM practices not included in this work that may also contribute to the better development and implementation of the 
archetypes. In addition, other organizational antecedents of the archetypes and how they create a competitive advantage can be studied.

One aspect that was not considered in this paper and might be taken into consideration in future works is risk management and leadership [82,83]. Leadership style could be a decisive factor in the development of environmental strategies [33]. Studies could also evaluate the effect of leadership style on economic and environmental performance.

Lastly, future research might also investigate several dependent variables or results linked to the archetypes, namely, economic and environmental performance, employee involvement, or eco-innovation. This analysis would be of great interest, given that each archetype could contribute to different outcomes. Thus, the entrepreneurial archetype, for example, could lead to eco-innovation [84], and the cooperative archetype could produce more efficient organizations [85].

Funding: This research received no external funding.

Institutional Review Board Statement: Not applicable.

Informed Consent Statement: Not applicable.

Data Availability Statement: Not applicable.

Acknowledgments: The author would like to thank Javier Martínez-del-Río and José Joaquín Céspedes-Lorente for their helpful comments and suggestions.

Conflicts of Interest: The author declares no conflict of interest.

\section{References}

1. Hawken, P.; Lovins, A.B.; Lovins, L.H. Natural Capitalism: Creating the Next Industrial Revolution, 1st ed.; Routledge: Boston, MA, USA, 1999.

2. Weinhofer, G.; Hoffmann, V.H. Mitigating climate change-how do corporate strategies differ? Bus. Strat. Environ. 2010, 19, 77-89. [CrossRef]

3. Qu, C.; Shao, J.; Cheng, Z. Can embedding in global value chain drive green growth in China's manufacturing industry? J. Clean. Prod. 2020. [CrossRef]

4. Xu, B.; Chen, W.; Zhang, G.; Wang, J.; Ping, W.; Luo, L.; Chen, J. How to achieve green growth in China's agricultural sector. J. Clean. Prod. 2020. [CrossRef]

5. Kastrinos, N. The future of Britain's green growth. Futures 1995, 27, 905-906. [CrossRef]

6. Mathews, J.A. Green growth strategies-Korean initiatives. Futures 2012, 44, 761-769. [CrossRef]

7. Vazquez-Brust, D.; Sarkis, J. Green Growth: Managing the Transition to a Sustainable Economy: Learning by Doing in East Asia and Europe, 1st ed.; Springer: Dordrecht, The Netherlands, 2012.

8. Aragón-Correa, J.A.; Sharma, S. A contingent resource-based view of proactive corporate environmental strategy. Acad. Manag. Rev. 2003, 28, 71-88. [CrossRef]

9. Bansal, P.; Roth, K. Why companies go green: A model of Ecological Responsiveness. Acad. Manag. J. 2000, 43, 717-736.

10. Roome, N. Developing environmental management strategies. Bus. Strat. Environ. 1992, 1, 11-24. [CrossRef]

11. Aragón-Correa, J.A. Strategic proactivity and firm approach to the natural environment. Acad. Manag. J. 1998, $41,556-567$. [CrossRef]

12. Sharma, S. Managerial Interpretations and Organizational Context as Predictors of Corporate Choice of Environmental Strategy. Acad. Manag. J. 2000, 43, 681-697.

13. Hart, S.L. A Natural-Resource-Based view of the firm. Acad. Manag. Rev. 1995, 20, 986-1014. [CrossRef]

14. Martínez-del-Río, J.; Céspedes-Lorente, J. Competitiveness and legitimation: The logic of companies going green in geographical clusters. J. Bus. Ethics 2014, 120, 131-146. [CrossRef]

15. Boiral, O. Tacit knowledge and environmental management. Long Range Plann. 2002, 35, 291-317. [CrossRef]

16. Kitazawa, S.; Sarkis, J. The relationship between ISO 14001 and continuous source reduction programs. Int. J. Oper. Prod. Man. 2000, 20, 225-248. [CrossRef]

17. Russo, M.V.; Fouts, P.A. A resource-based perspective on corporate environmental performance and profitability. Acad. Manag. J. 1997, 40, 534-559.

18. Bohnsack, R.; Pinkse, J.; Kolk, A. Business models for sustainable technologies: Exploring business model evolution in the case of electric vehicles. Res. Policy 2014, 43, 284-300. [CrossRef]

19. Schaltegger, S.; Wagner, M. Sustainable entrepreneurship and sustainability innovation: Categories and interactions. Bus. Strat. Environ. 2011, 20, 222-237. [CrossRef] 
20. Labella-Fernández, A.; Martínez-del-Río, J. Green Human Resource Management. In Responsible Consumption and Production. Encyclopedia of the UN Sustainable Development Goals, 1st ed.; Leal Filho, W., Azul, A., Brandli, L., Özuyar, P., Wall, T., Eds.; Springer: Cham, Switzerland, 2019.

21. Aragón-Correa, J.A.; Hurtado-Torres, N.; Sharma, S.; García-Morales, V.J. Environmental strategy and performance in small firms: A resource-based perspective. J. Environ. Manag. 2008, 86, 88-103. [CrossRef]

22. Ramus, C.A.; Steger, U. The roles of supervisory support behaviors and environmental policy in employee "Ecoinitiatives" at leading-edge European companies. Acad. Manag. J. 2000, 43, 605-626.

23. Schuler, R.; Jackson, S. Human resource management and organizational effectiveness: Yesterday and today. J. Organ. Eff. People Perform. 2014, 1, 35-55. [CrossRef]

24. Sheehan, M. Human resource management and performance: Evidence from small and medium-sized firms. Int. Small Bus. J. 2014, 32, 545-570. [CrossRef]

25. Renwick, D.W.S.; Redman, T.; Maguire, S. Green Human Resource Management: A Review and Research. Agenda. Int. J. Manag. Rev. 2013, 15, 1-14. [CrossRef]

26. Aragón-Correa, J.A. Beyond ourselves: Building bridges to generate real progress on sustainability management issues. Organ. Environ. 2013, 26, 3-6. [CrossRef]

27. Ashraf, F.; Ashraf, I.; Anam, W. Green HR for businesses. Int. J. Aca. Res. Bus. Soc. Sci. 2015, 5, 149-156. [CrossRef]

28. Anwar, N.; Nik Mahmood, N.H.; Yusliza, M.Y.; Ramayah, T.; Noor Faezah, J.; Khalid, W. Green Human. Resource Management for organisational citizenship behaviour towards the environment and environmental performance on a university campus. $J$. Clean. Prod. 2020, 256. [CrossRef]

29. Guerci, M.; Longoni, A.; Luzzini, D. Translating stakeholder pressures into environmental performance-The mediating role of green HRM practices. Int. J. Hum. Resour. Manag. 2016, 27, 262-289. [CrossRef]

30. Roscoe, S.; Subramanian, N.; Jabbour, C.J.C.; Chong, T. Green human resource management and the enablers of green organisational culture: Enhancing a firm's environmental performance for sustainable development. Bus. Strateg. Environ. 2019, 28, 737-749. [CrossRef]

31. Iqbal, Q. The Era of Environmental Sustainability: Ensuring That Sustainability Stands on Human Resource Management. Glob. Bus. Rev. 2020, 21, 377-391. [CrossRef]

32. Mousa, S.K.; Othman, M. The impact of green human resource management practices on sustainable performance in healthcare organisations: A conceptual framework. J. Clean. Prod. 2020, 243. [CrossRef]

33. Lopez-Cabrales, A.; Valle-Cabrera, R. Sustainable HRM strategies and employment relationships as drivers of the triple bottom line. Hum. Resour. Manag. R. 2020, 30. [CrossRef]

34. Jackson, S.E.; Renwick, D.W.; Jabbour, C.J.; Muller-Camen, M. State-of-the-art and future directions for green human resource management: Introduction to the special issue. Ger. J. Hum. Resour. Manag. 2011, 25, 99-116. [CrossRef]

35. Milliman, J. Leading-edge green human resource practices: Vital components to advancing environmental sustainability. Environ. Qual. Manag. 2013, 23, 31-45. [CrossRef]

36. Daily, B.F.; Bishop, J.W.; Govindarajulu, N. A conceptual model for organizational citizenship behavior directed toward the environment. Bus. Soc. 2009, 48, 243-256. [CrossRef]

37. Huber, G.P. Organizational learning: The contributing processes and the literatures. Organ. Sci. 1991, 2, 88-115. [CrossRef]

38. Levitt, B.; March, J.G. Organizational learning. Annu. Rev. Sociol. 1988, 14, 319-340. [CrossRef]

39. Fiol, C.M.; Lyles, M.A. Organizational learning. Acad. Manag. Rev. 1985, 10, 803-813. [CrossRef]

40. Meyer, A.D. Adapting to environmental jolts. Admin. Sci. Quart. 1982, 27, 515-537. [CrossRef]

41. March, J.G. Exploration and exploitation in organizational learning. Organ. Sci. 1991, 2, 71-87. [CrossRef]

42. McGrath, R.G. Exploratory learning, innovative capacity, and managerial oversight. Acad. Manag. J. 2001, 44, 118-132.

43. Vermeulen, F.; Barkema, H. Learning through acquisitions. Acad. Manag. J. 2001, 44, 457-476.

44. He, Z.L.; Wong, P.K. Exploration vs. exploitation: An empirical test of the ambidexterity hypothesis. Organ. Sci. 2004, 15, 481-494. [CrossRef]

45. Dewar, R.D.; Dutton, J.E. The adoption of radical and incremental innovations: An empirical analysis. Manag. Sci. 1986, 32, 1422-1433. [CrossRef]

46. Katila, R.; Ahuja, G. Something old, something new: A longitudinal study of search behavior and new product introduction. Acad. Manag. J. 2002, 45, 1183-1194.

47. Kang, S.; Morris, S.S.; Snell, S.A. Relational archetypes, organizational learning, and value creation: Extending the human resource architecture. Acad. Manag. Rev. 2007, 32, 236-256. [CrossRef]

48. Schulz, M. The uncertain relevance of newness: Organizational learning and knowledge flows. Acad. Manag. J. 2001, 44, 661-681.

49. Henderson, R.M.; Clark, K.B. Architectural innovation: The reconfiguration of existing product technologies and the failure of established firms. Admin. Sci. Quart. 1990, 35, 9-30. [CrossRef]

50. Henderson, R.; Cockburn, I. Measuring competence? Exploring firm effects in pharmaceutical research. Strat. Manag. J. 1994, 15, 63-84. [CrossRef]

51. Matusik, S.F.; Hill, C.W. The utilization of contingent work, knowledge creation, and competitive advantage. Acad. Manag. Rev. 1998, 23, 680-697. [CrossRef] 
52. McCaughey, S.L. Strategic interventions in intellectual asset flow. Acad. Manag. Rev. 2002, 27, 248-274. [CrossRef]

53. Nelson, R.R.; Winter, S.G. An Evolutionary Theory of Economic Change, 1st ed.; Harvard University Press: Cambridge, MA, USA, 1982.

54. Tallman, S.; Jenkins, M.; Henry, N.; Pinch, S. Knowledge, Clusters, and Competitive Advantage. Acad. Manag. Rev. 2004, 29, 258-271. [CrossRef]

55. Kogut, B.; Zander, U. Knowledge of the firm, combinative capabilities and the replication of technology. Organ. Sci. 1992, 3, 387-397. [CrossRef]

56. King, A.W.; Ranft, A.L. Capturing knowledge and knowing through improvisation: What managers can learn from the thoracic surgery board certification process. J. Manag. 2001, 27, 255-277. [CrossRef]

57. Lane, P.J.; Lubatkin, M. Relative absorptive capacity and interorganizational learning. Strat. Manag. J. 1998, 19, 461-477. [CrossRef]

58. Birkinshaw, J.; Gupta, K. Clarifying the distinctive contribution of ambidexterity to the field of organization studies. Acad. Manag. Perspect. 2013, 27, 287-298. [CrossRef]

59. Porter, M.E. Competitive advantage, agglomeration economies, and regional policy. Int. Regional Sci Rev. 1996, 19, 85-90. [CrossRef]

60. Adler, P.S. Building better bureaucracies. Acad. Manag. Perspect. 1999, 13, 36-47. [CrossRef]

61. Casadesus-Masanell, R.; Crooke, M.; Reinhardt, F.; Vasishth, V. Households' willingness to pay for "green" goods: Evidence from Patagonia's introduction of organic cotton sportswear. J. Econ. Manag. Strat. 2009, 18, 203-233. [CrossRef]

62. Young, W.; Tilley, F. Can businesses move beyond efficiency? The shift toward effectiveness and equity in the corporate sustainability debate. Bus. Strat. Environ. 2006, 15, 402-415. [CrossRef]

63. Brundtland, G.H.; Khalid, M.; Agnelli, S.; Al-Athel, S.; Chidzero, B.J.N.Y. Our Common Future; UN: New York, NY, USA, 1987.

64. Gulati, R.; Puranam, P. Renewal through reorganization: The value of inconsistencies between formal and informal organization. Organ. Sci. 2009, 20, 422-440. [CrossRef]

65. Dunphy, D.; Griffiths, A.; Benn, S. Organization Change for Corporate Sustainability, 2nd ed.; Routledge: London, UK, 2007.

66. Lenox, M.; York, J.G. Environmental entrepreneurship. In The Oxford Handbook of Business and Natural Environment, 1st ed.; Bansal, P., Hoffman, A.J., Eds.; Oxford University Press: New York, NY, USA, 2002; pp. 70-92.

67. York, J.G.; Venkataraman, S. The entrepreneur-environment nexus: Uncertainty, innovation, and allocation. J. Bus. Venturing 2010, 25, 449-463. [CrossRef]

68. Ramus, C.A. Organizational support for employees: Encouraging creative ideas for environmental sustainability. Calif. Manag. Rev. 2001, 43, 85-105. [CrossRef]

69. Cotton, J.L. Employee Involvement: Methods for Improving Performance and Work Attitudes, 1st ed.; Sage Publications: Newbury Park, CA, USA, 1993.

70. Wright, P.M.; Dunford, B.B.; Snell, S.A. Human resources and the resource based view of the firm. J. Manag. 2001, $27,701-721$. [CrossRef]

71. Vidal-Salazar, M.D.; Cordón-Pozo, E.; Ferrón-Vilchez, V. Human resource management and developing proactive environmental strategies: The influence of environmental training and organizational. Hum. Resour. Manag. 2012, 51, 905-934. [CrossRef]

72. Perron, G.M.; Cote, R.P.; Duffy, J.F. Improving environmental awareness training in business. J. Clean. Prod. 2006, 16, 551-562. [CrossRef]

73. Anderson, L.M.; Bateman, T.S. Individual environmental initiative: Championing natural environmental issues in US business organizations. Acad. Manag. J. 2000, 43, 548-570.

74. Martínez-del-Río, J.; Céspedes-Lorente, J.; Carmona-Moreno, E. High-involvement work practices and environmental capabilities: How HIWPS create environmentally based sustainable competitive advantages. Hum. Resour. Manag. 2012, 51, 827-850. [CrossRef]

75. Govindarajulu, N.; Daily, B.F. Motivating employees for environmental improvement. Ind. Manag. Data Syst. 2004, 104, 364-372. [CrossRef]

76. Patton, K.R.; Daley, D.M. Gain sharing in Zebulon: What do workers want? Public Pers. Manag. 1998, 27, 117-131. [CrossRef]

77. Calia, R.C.; Guerrini, F.M.; de Castro, M. The impact of six sigma in the performance of a pollution prevention program. J. Clean. Prod. 2009, 17, 1303-1310. [CrossRef]

78. Jackson, S.E.; Seo, J. The greening of strategic HRM scholarship. Organ. Manag. J. 2010, 7, 278-290. [CrossRef]

79. Lawler, E.E., III. Motivation in Work Organizations, 1st ed.; Brooks/Cole Publishing: Monterey, CA, USA, 1973.

80. Enander, R.T.; Pannullo, D. Employee involvement and pollution prevention. J. Qual. Particip. 1990, 1, 50-53.

81. Pérez-Valls, M.; Céspedes-Lorente, J.; Martínez-del-Río, J.; Antolín-López, R. How organizational structure affects ecological responsiveness. Bus. Soc. 2019, 58, 1634-1670.

82. Kurucz, E.C.; Colbert, B.A.; Luedeke-Freund, F.; Upward, A.; Willard, B. Relational leadership for strategic sustainability: Practices and capabilities to advance the design and assessment of sustainable business models. J. Clean. Prod. 2017, 140, 189-204. [CrossRef]

83. Redekop, B.W. Leadership for Environmental Sustainability, 1st ed.; Routledge: New York, NY, USA; London, UK, 2010. 
84. Adams, R.; Jeanrenaud, S.; Bessant, J.; Denyer, D.; Overy, P. Sustainability-oriented innovation: A systematic review. Int. J. Manag. Rev. 2016, 18, 180-205. [CrossRef]

85. Miron, E.; Erez, M.; Naveh, E. Do personal characteristics and cultural values that promote innovation, quality, and efficiency compete or complement each other? J. Organ. Behav. 2004, 25, 175-199. [CrossRef] 